УДК $80 ; 003 ; 004$

\title{
Network Digital Communication \\ from the General Philological Point of View: the Fifth Texture of Speech
}

\author{
Igor E. Kim* \\ Institute of Philology of SB RAS \\ 8 Academician Nikolaeva st., Novosibirsk, 630090, Russia
}

Received 02.04.2016, received in revised form 27.05.2016, accepted 12.06.2016

The article is an attempt to understand the place of network digital communication (NDC) in the general communicative interaction structure organized by people. To describe the communicative potential of NDC, the concept of texture of speech introduced by Iu. V. Rozhdestvenskii is used, which is a material substratum of the language communication forming a new type of social language practice. NDC as a texture of speech forms innovations: full-scale negotiation of spatial, temporal and even environmental limits of the previous textures of speech; consolidation of the communicative addressee's role due to the choices of the software interfaces; new way of existence of text as a distributed hypertext and structured database (L. Manovich). New issues of communication caused by $N D C$ are: the further alienation of the communicant from the text and other communicants, and the leading role the interface designers and, in general, IT-specialists play in communication.

Keywords: web communication, texture of speech, speech, writing, printing, mass media, IT-technologies in language communication.

DOI: 10.17516/1997-1370-2016-9-7-1586-1593.

Research area: philology.

As the most successful incarnation of network digital communication (hereinafter referred to as NDC), the Internet has irrevocably entered the life of the world community. It happened faster than the community could realize what this phenomenon does in the arrangement of human communication. The stupendous opportunities of the Internet as the means of transmitting, receiving, processing and storing information make the society pay greater attention to the prospective of this communicative phenomenon than to interpretation and inclusion of it into the communicative tradition.
The article is an attempt to understand the place of network digital communication (NDC) in the general communicative interaction structure organized by people. To do this attempt, it is convenient to use the concept of texture of speech adopted from general philology.

The texture of speech was introduced into general philology by Iu.V. Rozhdestvensky. In his Introduction into General Philology course he used this concept to refer to the tangible embodiment of language signs having physical properties and thereby changing the habitual forms of social and

(C) Siberian Federal University. All rights reserved

* Corresponding author E-mail address: kimkim@krasu.ru 
linguistic practice [Rozhdestvensky, 1996. P. 21 and further].

Iu.V. Rozhdestvensky outlines four textures of speech based on the peculiarities of the language sign production:

1) spoken;

2) written;

3) printed;

4) electronic, or mass communication.

There are many consequences of the emergence of each new texture:

1) emergence of new ways of sign production, evolving from natural ability to technology;

2) emergence of a new way of text and knowledge existence: a text complicates from a reproducible sequence of acoustic signs to a compact electromagnetic form of existence; knowledge complicates from the abstract to the immediate "here and now" representation formed by articulated speech, to the actual information distributed to the anonymous audience of mass media;

3) involvement of new participants and even institutions into standard communication: from the specific roles of the speaker to creation of media corporations;

4) negotiation of communication restrictions: from the immediate, contact individual communication to the communication of a corporate author with the massive addressee;

5) for this reason, emergence of new restrictions and problems: from the loss of spontaneity to the totality of the information space.

Let us take a closer look at these.

\section{Emergence of new ways of sign production}

The spoken texture is connected to speech, which is a natural ability of human, though acquired in the course of evolution. It is proved, first of all, by the fact that in his ontogeny the human learns speech naturally by a certain age with no special teaching efforts. Indeed, there are certain types of spoken speech which do require special teaching, such as some genres of public speech, recitation, theatre speech, some forms of business speech; however, all of them are connected with specific kinds of activities and communication conditions, which are different from standard personal everyday communication.

In this regard, writing is considered as a form of craft laced with art. It requires special teaching and tools: an instrument, a surface, and, depending on the types of the first and the latter, some dyeware, such as writing ink, Chinese ink, or any other. From this point, language communication begins to pollute the environment, though before the period of technology (public communication) writing materials and products were natural and easy to dispose [Kim, 2014].

Press is an industry with all of its typical attributes: editors as entrepreneurs, printing houses as manufacturing facilities, and sales outlets. A text becomes a means of earning, creating copyright.

Mass communication is connected with the voluntariness and intensive development of "language technologies", from the most basic newspaper to modern electronic typing, radio and television communication.

\section{Emergence of a new way of text and knowledge existence}

Emergence of speech caused existence of reproducible sequences of signs able to model the world. In its turn, it led to the development of abstract knowledge as a non-reflexible linguistic world image, traditions (mindsets), folklore as an analogue of history and rumour (talks) [Rozhdestvensky, 1996. P.30 and further]. 
Invention of writing is associated with the creation of unique manuscripts able to keep knowledge statically as documents to be transmitted from generation to generation for as long as the writing material allows. There appeared history which turned time from cyclic to linear; knowledge was alienated from its initial keeper.

Press provided an opportunity to publish text in tens, hundreds, thousands of identical copies, spreading information with enormous coverage of reading audience. There appeared books as a form of culture, fiction as leisure reading; there developed science.

Mass communication makes existence of text diverse and varied. The greatest achievement of text existence is its electromagnetic form, from telegraph to magnetic media.

\section{Involvement of new participants and even institutions into standard communication}

Even spoken speech limited with the capacities of our articulation and hearing apparatus creates several important roles. The most important ones are the Speaker and the Listener, the parties of the most basic everyday dialogue. However, public speech assumes the position of a specific speaker, an orator, or a crier acting as an intermediary for persons with high social status. For long-distance communication, a messenger is required.

Emergence of writing creates a great number of social communication institutions: scriptoriums for creation and copying of texts, mail and Feldjägers for long-distance delivery of texts, chancelleries for document processing, libraries and archives for storage, schools for teaching. There appears craft of paper manufacturing, writing instruments, dye and ink.

Press creates vacancies for the entrepreneur editor, who hires editors and correctors for manuscript processing, printing houses as manufacturing facilities where qualified typists work, and book stores as sales outlets. Censors and literary critics come next.

Mass communication creates many technical professions, as well as editorial offices and journalists as intermediaries between the authorities and the population.

\section{Negotiation of communication restrictions}

One of the main limits of communications negotiated with spoken speech is involuntariness. Making up a model of reality, articulated speech distracts oneself from the actual situation.

Writing negotiates temporal and spatial limits caused by the dynamicity of an acoustic sign, non-perfection of the articulating and hearing apparatus of human.

Press expands the audience and negotiates the uniqueness, singularity of text explained by the craft nature of writing.

Mass communication, first of all, accelerates the transmission of text from the author to the addressee. Moreover, it solves a number of other technical problems, including weakness of human voice; it also transmits and saves dynamic speech.

\section{Emergence of new restrictions and problems}

Formation of voluntary communication, created with the emergence of spoken language, leads, to a certain extent, to the loss of spontaneity and naturalness. This tendency is consolidated by the emergence and development of the textures of speech.

Writing requires compulsory teaching and a tool for text creation. The average time of learning and the totality of teaching are still growing. Moreover, in comparison with speech, the speed of text generation slows down, 
causing the emergence of a specific social role for professional production of text: a penman, a scrivener, a typist, a stenographer etc.

The distributed character of text production in press communication requires that the reader has sufficient money to buy the book, and deprives the text author of the authorship right. Moreover, the hierarchy of roles in communications also changes: an important role is played by communication intermediaries, the editor and the bookseller, see: Inspiration is not for sale, / But you can sell a manuscript (Pushkin A.S. Conversation Between a Bookseller and a Poet).

Mass communication gives rise to information totality, impossibility of hiding from the influence of mass media which may be conscious and/or negative. See the periphrasis of the common expression: mass media is "the fourth estate".

What place in this range does network digital communication occupy?

These two terms: network communication as a social form of interaction and digital communication as a form of text existence are not strictly connected. There is network communication which does not use digital technologies, such as communication of stamp collectors, other communities of people with the same interests, or multilevel marketing. A computer may also be used without connection to other computers and means of communication, which was practiced for a long time with the use of regular personal computers.

However, it was connection of digital means of communication into a network which caused the emergence of the new texture of speech.

1. It requires the presence of two interconnected, relatively new technologies: a) a digital technology, particularly, digital coding of information of any type with subsequent processing of the information by means of electronic devices; b) a web technology, i.e. a way of transmitting the coded information through electric and optical network the virtual network is based on. Digital coding and information processing allow people to perform communication at a very high speed. To compare, let us imagine such specific network form of communication as traditional correspondence chess. It is played in a network, i.e. every player plays with every other player. Unlike overboard chess where time is quantized into tours and the pairs of players are strictly separated, in correspondence chess a player plays with all of his opponents in voluntary order, sending his moves by mail. As sending a message by mail takes a long time, and the duration of each game is individual, the time of tournament is limited by rules, but also determined by the duration of the longest game and the speed of mail delivery. The duration of such game may count up to dozens or even hundreds of days, and the time of each move may take days. Unlike the web based on regular mail messages, posting a text in the Internet, let alone replying with an audio or a video message takes time comparable to that of spoken communication.

The web nature of communication changes the relationships between the author and the addressee. If the author uses any individual means of communication, i.e. writes an electronic message, makes an individual audial or visual contact, it is not deemed to be specific web communication. The author is deemed part of web communication only if he post a text or a dynamic message in the part of web open for a large number of users. In this situation, the addressee finds the message using information search tools. In this regard, NDC is similar to mass communication, but due to the open nature of the web, the role of an addressee is much more active. Even in comparison with cable television 
which concentrates hundreds of channels, in the Internet an addressee may find many more messages posted by millions of authors.

Universality, speed of transmission, principal openness and potential activeness of the addressee make the NDC a new texture of speech different from others.

2. The way of text existence is paradoxical: digital coding allows not to make a difference between visual, audial and textual existence of knowledge. The difference, then, is quantitative, and constitutes one-three orders in the following sequence: symbolic coding of text - graphic image - audio file - video file. Another new important property of text existence is an opportunity of non-linear organization of any kind of data [Manovich, 1998; 2001. P. 194-212]. Here I would like to distinguish between two cases: a hypertext and a database. A hypertext as a technology which allows to make a reference not only to fragments of the given text, but also to other texts, physically and virtually located in different places. Therefore, there occurs a nonlinear structure with reference-link points. A database as a specific kind of text was described by L. Manovich [1998, 2001. P. 194-212]. He contrasts a linear text he refers to, though not accurately from philological point of view, as a narrative text, to a database as a new form of text, which interacts with the addressee through its interface, adjustable to this or that extent. The peculiarity of this interaction between the "reader" and the "text" is a greater degree of voluntariness in the addressee's activity, than that in the interaction with a standard, linear text. It means that a database as a text also has a software interface, unlike a written or printed text, the interaction with the addressee of which is only determined by the reading culture of the latter.

Such degree of "classification" of knowledge to the database epoch was previously presented only in tables and card catalogues.
However, there also exists an opposite tendency: atomic, certain knowledge, specifically that intended for social adaptation, often exists as a ready text, not a totality of ideas. Such existence of knowledge is provided by the convenience of digital form of storing and processing of a ready text. This way, spoken transmission of knowledge requires attention, intellect, memory, and active language skills for further knowledge transmission. In written communication, a manuscript retains its individual features, and the addressee would hardly be able to claim the text as his own. To do it, he would have to, at least, re-write it. On the other hand, a small community of literate people often know original texts, their authors' styles etc. well enough to distinguish between the original and the copy. High cost of press does not allow to claim a printed text as one's own. Technical means of photocopying give the copy some distinctive textural features which do not allow to use a copy as the original.

Electronic existence of text, as well as availability and low cost of text processing and transmission, which do not save any individual textural features, allow to use ready texts and compile them, claiming them as your own.

3. Digital network formed up a specific kind of a social language practice, where the intermediary role is played by interface, or the automatic system of data access. The communication addressee, who has commonly been considered to be a passive party of communication, has a limited opportunity to change the settings of such interface. One of the problems is that the developer of the interface, the owner of the web and the information keeper can control communication within the web. Thus, communicative skills acquire a more technical character. This way, the ability to use the interface on a level exceeding 
the needs of a regular participant of web communication, creates the opportunity to get information made for limited audience. Being an integral part of communication, data search systems, web browsers, online applications and the infrastructure of the web itself become new parties of communication, just like the phenomena themselves were regarded as a system of "phenomenon + measurement gauge" in the microworld researches of Neoclassic Physics [Bessonov, 1986].

Another interesting aspect of social and communicative practice in the digital network is blogs (online journals).

The history of blog development is very interesting. At first, a blog was a specific place for storing an individual user's links to interesting web pages. At a certain moment it was found that such set of links commented by the user and some links themselves may be interesting for other web users as well. As time passed, posts on the blog platform http://www.livejournal.com or a social network (vk, Facebook, Odnoklassniki, Twitter, Instagram) became a source of actual information, comparable to an item published or broadcast by mass media. As a result, in Russia bloggers ("owners of websites and (or) pages of websites in the Internet, hosting public information and with the daily access of over three thousand users of the Internet") are now legally equalled to mass media [Federal Law No. 97-FZ dated May 5, 2014].

4. NDC makes its contribution into the negotiation of limits of language communication connected with the specificity of other textures of speech.

The greatest achievement of NDC is the restriction in the totality of communication caused by public communication. Due to the existence of an interface, the individual addressee may select appropriate information in the needed interpretation. However, nowadays, due to the automation of publishing and even text generation processes (bots), as well as due to the so-called information attacks (simultaneous appearance of scandalous information from several sources, similar to the creation of rumours in spoken communication), the capacity for manipulating the audience of regular web users rises greatly. We can also say that the increase of the degree of the addressee's voluntariness of selecting information in NDC is just a technical capacity which may be limited with communicative technologies based on the technical capacities of digital networks and peculiarities of social network behaviour.

5. Due to the availability and openness information, abstract knowledge loses its value for the addressee. The one searching for information in the Internet needs an additional pragmatic factor, a sort of competitive position of the author publishing information online. Such factor may be demonstration of solution for the task set by the addressee, applicability of the theme, briefness or captivating character of the text. One of the simplest, but the most essential parameters for any material posted online is its popularity assessed as a rating. Bringing some news, a website or a page to a high rating position is a conceptual, communicative, and, first of all, a technological task. For this reason, a good command of the interface, knowledge of search engine operation techniques and social network structure become an important component of communicative competence. Altogether they create communicative alienation, i.e. the absence of necessity for the addressee to identify the author of the text.

This way, network digital communication is a new, independent texture of speech with a complete set of consequences, which may presented in a table as follows: 


\begin{tabular}{|l|l|}
\hline Peculiarities of a texture of speech & \multicolumn{1}{c|}{ Network digital communication } \\
\hline Way of sign production & Combination of technologies with a non-linear effect \\
\hline Way of text existence & Digital coding of characters \\
\hline Way of knowledge existence & $\begin{array}{l}\text { 1. In a "decomposed" way, but combined with the interface } \\
\text { 2. As a ready text }\end{array}$ \\
\hline Communication parties & $\begin{array}{l}\text { Web corporations, programmers, electronic specialists, system } \\
\text { administrators }\end{array}$ \\
\hline Negotiated limits & Inactiveness of the addressee \\
\hline New limits & Dependence on gadgets, communicative alienation \\
\hline
\end{tabular}

\title{
References
}

Bazhenov, A. A. (1986) Kopengagenskaia interpretatsiia i problema primenimosti fizicheskikh poniatiy [Copenhagenian interpretation and the problem of application of physical concepts], In Interpretaciia kak istoriko-nauchnaia i metodologicheskaia problema [Interpretation as historicalscientific and methodological problem]. Novosibirsk, Nauka, pp. 120-138.

Manovich, L. (2001) The Language of New Media. Cambridge.

Kim, I. E. (2014). Iazykovaia tekhnologiia i okruzhaiushchaia sreda (k postanovke problemy) [Language technology and environment (stating the problem), In Ekologiia iazyka i kommunikativnaia praktika [Language ecology and communicative practice], 1, pp. 38-44.

Rozhdestvenskii, Iu. V. (1996) Obshchaia filologiia [General philology]. Moscow, Fond "Novoe tysiacheletie".

Federal law No 97-FZ of 5 May 2014 "On amendments being made to Federal law 'On information, information technologies and on information protection' and certain legislative acts of the Russian Federation concerning regulation the information sharing with the use of information and telecommunication networks". Available at: http://www.consultant.ru/document/cons_doc_ LAW_162586/(accessed 31 March 2016).

\section{Сетевая цифровая коммуникация}

\section{с точки зрения общей филологии: пятая фактура речи}

\author{
И.Е. Ким \\ Институт филологии СО РАН \\ Россия, 630090, Новосибирск, ул. Академика Николаева, 8
}

Настоящчая статья представляет собой попытку осмысления места сетевой ичифровой коммуникации (СЦК) вобщейструктурекоммуникативныхвзаимодействий, организованных человечеством. Для описания коммуникативного потенциала СЦК используется введенное в иирокий научный оборот Ю.В. Рождественским понятие фактуры речи, представляющей собой материальный субстрат языковой коммуникации, формирующий новый тип общественно-языковой практики. СЦК как фактура речи формирует инновации: комплексное преодоление пространственных, временных и даже средовых ограничений, свойственных предыдущим фактурам речи; усиление роли коммуникативного 
адресата за счет возможностей выбора, предоставляемого интерфейсами программных продуктов; новый способ существования текста в виде распределенного гипертекста и структурированной базы данных (Л. Манович). Новыми проблемами коммуникации, порождаемыми СЦК, являются еще большее отчуждение коммуниканта от текста и от других коммуникантов, а также доминирующая роль в коммуникаиии разработчиков интерфейсов и в целом специалистов в IT-технологиях.

Ключевые слова: сетевая коммуникация, фактура речи, речь, письмо, печать, СМИ, IT-технологии в языковой коммуникации.

Научная специиальность: 10.00.00 - филологические науки. 